\title{
The transcription factor c-Fos coordinates with histone Iysine-specific demethylase $2 A$ to activate the expression of cyclooxygenase-2
}

\author{
Shaoli Lu ${ }^{1, *}$, Yang Yang ${ }^{1, *}$, Yipeng Du ${ }^{1}$, Lin-lin Cao ${ }^{1}$, Meiting Li ${ }^{1}$, Changchun Shen ${ }^{1}$, \\ Tianyun Hou ${ }^{1}$, Ying Zhao', Haiying Wang ${ }^{1}$, Dajun Deng ${ }^{2}$, Lina Wang ${ }^{1}$, Qihua He ${ }^{3}$, \\ Wei-Guo Zhu' ${ }^{1,4}$ \\ ${ }^{1}$ Key Laboratory of Carcinogenesis and Translational Research (Ministry of Education), State Key Laboratory of Natural \\ and Biomimetic Drugs, Beijing Key Laboratory of Protein Posttranslational Modifications and Cell Function, Department of \\ Biochemistry and Molecular Biology, Peking University Health Science Center, Beijing 100191, China \\ ${ }^{2}$ Department of Etiology, Peking University School of Oncology and Beijing Cancer Hospital \& Institute, Beijing 100142, China \\ ${ }^{3}$ Center of Medical and Health Analysis, Peking University Health Science Center, Beijing 100871, China \\ ${ }^{4}$ Peking University-Tsinghua University Joint Center for Life Sciences, Beijing 100751, China \\ *These authors contributed equally to this work
}

Correspondence to:

Wei-Guo Zhu, e-mail: zhuweiguo@hsc.pku.edu.cn

Yang Yang, e-mail: yangsh@bjmu.edu.cn

Keywords: COX-2, c-Fos, KDM2A, histone methylation

Received: April 28, $2015 \quad$ Accepted: September 15, $2015 \quad$ Published: September 25, 2015

\section{ABSTRACT}

Cyclooxygenase-2 (COX-2) is overexpressed in a variety of human epithelial cancers, including lung cancer, and is highly associated with a poor prognosis and a low survival rate. Understanding how $\mathrm{COX}-2$ is regulated in response to carcinogens will offer insight into designing anti-cancer strategies and preventing cancer development. Here, we analyzed $C O X-2$ expression in several human lung cancer cell lines and found that COX-2 expression was absent in the $\mathrm{H719}$ and $\mathrm{H} 460$ cell lines by a DNA methylation-independent mechanism. The re-expression of COX-2 was observed after 12-0-tetradecanoylphorbol-13-acetate (TPA) treatment in both cell lines. Further investigation found that H3K36 dimethylation was significantly reduced near the COX-2 promoter because histone demethylase 2A (KDM2A) was recruited to the COX-2 promoter after TPA treatment. In addition, the transcription factor c-Fos was found to be required to recruit KDM2A to the COX-2 promoter for reactivation of COX-2 in response to TPA treatment in both the $\mathrm{H719}$ and $\mathrm{H} 460$ cell lines. Together, our data reveal a novel mechanism by which the carcinogen TPA activates $\mathrm{COX}-2$ expression by regulating $\mathrm{H} 3 \mathrm{~K} 36$ dimethylation near the $\mathrm{COX}-2$ promoter.

\section{INTRODUCTION}

Lung cancer is the leading cause of cancer-related mortality in the world. The overall 5-year survival rate is approximately $15 \%$ for lung cancer patients, and this rate has remained largely unchanged for the last three decades $[1,2]$. Even when this cancer is detected early, up to $50 \%$ of patients with pathologic stage I disease eventually relapse post-resection, and the median survival is less than one year [3]. Therefore, there is an urgent need to find a novel strategy that offers significant improvements to prolong the survival of lung cancer patients.

Cyclooxygenase-2 (COX-2), an isoform of cyclooxygenase, is the rate-limiting enzyme in the synthesis of prostaglandins. It is an immediate-early response gene not expressed in most normal tissues but can be induced by cytokines, growth factors, phorbol esters, oncogenes and chemical carcinogens [4-6]. For example, 12-O-tetradecanoylphorbol-13-acetate (TPA) was reported to up-regulate the expression of the $C O X-2$ gene in the human lung cancer cell line A549 [6]. 
$C O X-2$ plays a significant role in lung cancer carcinogenesis, promotion, angiogenesis, invasion and metastasis [7]; therefore, $C O X-2$ has become an important target being evaluated for lung cancer therapy and chemoprevention [8]. Understanding the $C O X-2$ expression mechanism is therefore important for developing strategies to prevent and treat lung cancer.

The transcription factors upstream of COX-2, such as AP-1, p300/CBP and NF- $\mathrm{B}$, can be activated by a series of kinase reactions after certain types of stimulation $[9,10]$. The Fos family of transcription factors includes c-Fos, FosB, Fra-1 and Fra-2, as well as smaller FosB splice variants Fos B2 and delta FosB2 [11]. The Fos family genes encode leucine zipper proteins that can dimerize with Jun family proteins to form the transcription factor complex activating protein 1 (AP-1) [12]. c-Fos is a constituent of the first studied AP-1 protein complexes and is frequently overexpressed in tumor cells $[11,13]$. c-Fos has also been reported to increase the expression of $C O X-2$ [4], but it is not clear how c-Fos activates $C O X-2$ expression.

Epigenetic control of cancer-related gene expression plays a critical role in cancer development [14]. In mammalian cells, epigenetic modifications of cytosine residues of the DNA CpG dinucleotide and $\varepsilon$-amino residues of histones have emerged as the major determinants of chromatin remodeling and gene transcriptional regulation [15-17]. Both DNA methylation and histone modifications coordinate to regulate gene expression. DNA methylation, which occurs in the $\mathrm{CpG}$ islands in the gene promoter region, is strongly related to gene inactivation $[18,19]$. The absence of $C O X-2$ expression is closely correlated with the DNA methylation of the $C O X-2$ promoter, and 5-aza-2'-deoxycytidine, a DNA demethylating agent, can reactivate the expression of $C O X-2[20,21]$. In addition to DNA methylation, the modification of histones such as $\mathrm{H} 3 \mathrm{~K} 4, \mathrm{H} 3 \mathrm{~K} 9$ and $\mathrm{H} 3 \mathrm{~K} 27$ has also been reported to be an important factor in regulating the expression of $\mathrm{COX}-2$ $[17,22-25]$. In contrast to other histone methylation sites, the effect of $\mathrm{H} 3 \mathrm{~K} 36$ methylation on $\mathrm{COX}-2$ gene expression has not been extensively studied. H3K36me 2 has been reported to be enriched in the promoters of both expressed and silenced genes and thus plays an important role in the regulation of gene expression [17, 26, 27]. Several lysine methyltransferases (KMTs) and lysine demethylases (KDMs) are involved in H3K36 methylation [28]. For example, lysine-specific demethylase 2A (KDM2A) (also named JHDM1A) can demethylate H3K36me1/2 [29]. Whether there is a causal relationship between the enrichment of histone methylation-related enzymes such as KDM2A on the $C O X-2$ promoter and $C O X-2$ gene activation is worth investigating.

In this study, we analyzed the $C O X-2$ expression in several human lung cancer cell lines and found that the $C O X-2$ gene could be reactivated by TPA without affecting the DNA methylation status of the $C O X-2$ promoter. H3K36 dimethylation was significantly changed around the $C O X-2$ promoter after TPA treatment, and the changes in the H3K36 dimethylation were mediated by the transcription factor c-Fos, which recruited KDM2A to the $C O X-2$ promoter.

\section{RESULTS}

\section{2-O-tetradecanoylphorbol-13-acetate (TPA) activates the re-expression of the $C O X-2$ gene}

The $C O X-2$ gene is typically silent in most normal tissues and is overexpressed in many solid tumors, including lung cancer $[7,30]$. To investigate the $C O X-2$ expression status in human lung cancer cell lines, RT-PCR was performed in H719, H460, H23 and A549 cells. As shown in Figure 1A, COX-2 expression was absent in $\mathrm{H} 719$ and $\mathrm{H} 460$ cells but was high in $\mathrm{H} 23$ and A549 cells. To determine whether the $C O X-2$ gene could be re-expressed, 12-O-tetradecanoylphorbol-13-acetate (TPA), a potent carcinogen, was administered to both the H719 and H460 cell lines. $C O X-2$ expression was reactivated by TPA in a dose- and time-dependent manner in H719 and H460 cells as demonstrated by RT-PCR (Figure 1B and 1C). Reactivation of the $C O X-2$ gene peaked at 4-6 hrs after TPA treatment in both the H719 and H460 cells (Figure 1B and 1C), which was consistent with its protein levels as demonstrated by Western blotting (Figure 1D). These data indicate that $C O X-2$ can be reactivated by TPA in human lung cancer cells.

\section{TPA reactivates $C O X-2$ expression without affecting the DNA methylation status of its promoter but is associated with $\mathrm{H} 3 \mathrm{~K} 36$ methylation}

Because the DNA hypermethylation of the $\mathrm{COX}-2$ promoter is related to $C O X-2$ gene silencing [21], we assessed the DNA methylation status of this promoter in the H719, H460, H23 and A549 cell lines. Genomic DNA from these human lung cancer lines was extracted and treated with sodium bisulfite for methylation-specific PCR (MSP) analysis. As shown in Figure 2A, the methylated band was clearly detected in $\mathrm{H} 719$ cells, which indicates a hypermethylated $\mathrm{COX}-2$ promoter in $\mathrm{H} 719$ cells. Conversely, unmethylated bands were detected in the H460, H23 and A549 cells (Figure 2A). Remarkably, the $C O X-2$ gene was absent in $\mathrm{H} 460$ cells, but the DNA methylation status of the $C O X-2$ promoter in this cell line was unmethylated, which suggests that DNA methylation might not be related to $C O X-2$ gene expression in $\mathrm{H} 460$ cells. To further clarify the effect of DNA methylation on $C O X$-2 gene expression, the alteration of DNA methylation status of the $C O X-2$ promoter was assessed before and after TPA treatment in $\mathrm{H} 719$ cells. $\mathrm{H} 719$ cells were treated with TPA $(100 \mathrm{ng} / \mathrm{mL})$ for $6 \mathrm{hrs}$, and the genomic DNA 


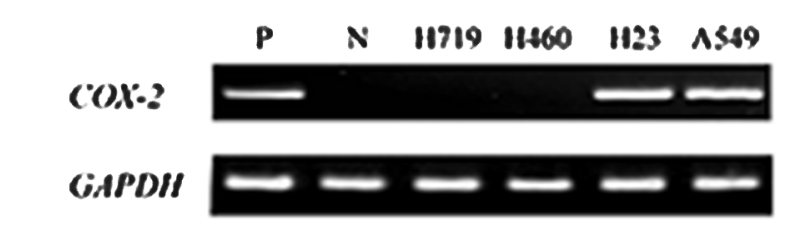

C
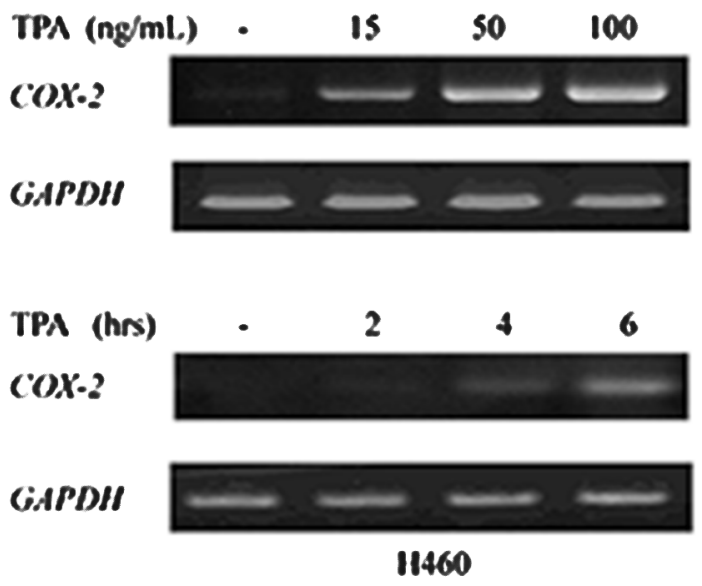

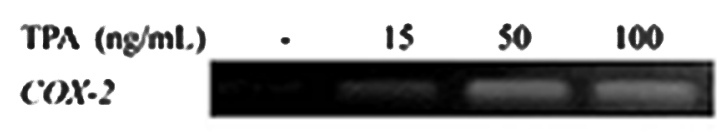

GAPDH

TPA (hrs)

cox:2

GAPDI
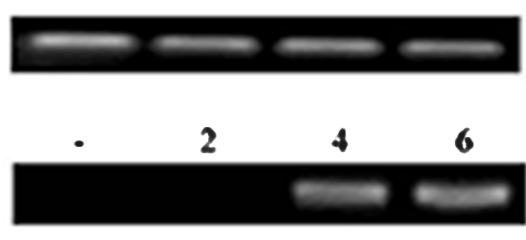

D

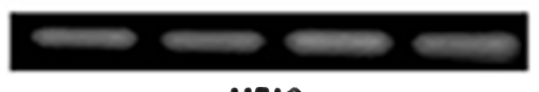

11719

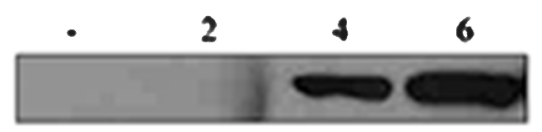

Bractin

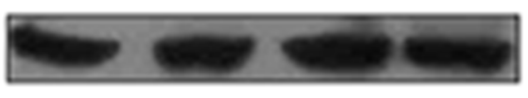

11719

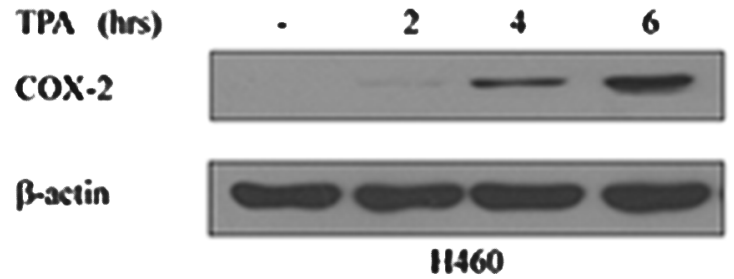

Figure 1: 12-O-tetradecanoylphorbol-13-acetate (TPA) activates the re-expression of $C O X-2$ gene. A. mRNAs from the human lung cancer cell lines H719, H460, H23 and A549 were extracted to detect COX-2 expression by RT-PCR. GAPDH was used as a loading control. P indicates a positive control, and $\mathrm{N}$ indicates a negative control. B. H719 cells were treated with TPA for 6 hrs at different doses $(0,15,50$ and $100 \mathrm{ng} / \mathrm{mL})$, or for different times $(0,2,4$ and $6 \mathrm{hrs})$ at $100 \mathrm{ng} / \mathrm{mL}$. RT-PCR was performed to detect $C O X-2 \mathrm{mRNA}$ levels after treatment. GAPDH was used as a loading control. C. H460 cells were treated with TPA for 6 hrs at different doses $(0,15,50$ and $100 \mathrm{ng} / \mathrm{mL})$, or for different times $(0,2,4$ and $6 \mathrm{hrs})$ at $100 \mathrm{ng} / \mathrm{mL}$. RT-PCR was performed to detect the $C O X-2 \mathrm{mRNA}$ levels after treatment. GAPDH was used as a loading control. D. H719 and H460 cells were treated with TPA for different times $(0,2,4$ and 6 hrs $)$ at $100 \mathrm{ng} / \mathrm{mL}$, and proteins were extracted to detect the expression of COX-2 at the protein level by Western blotting. $\beta$-actin is shown as a loading control.

was extracted for MSP. Surprisingly, the DNA methylation status of the $C O X-2$ promoter was unchanged after TPA treatment as detected by MSP (Figure 2B). Consistently, this unaltered methylation pattern was also confirmed by bisulfite sequencing analysis. The methylated $\mathrm{CpG}$ levels within the $C O X-2$ promoter, which contains $18 \mathrm{CpG}$ dinucleotides, were $62.0 \%$ and $60.6 \%$ before and after TPA treatment in $\mathrm{H} 719$ cells, respectively (Figure 2C). To clarify whether TPA treatment induced a change in the binding activity of methyl-CpG binding domain (MBD) proteins on the $C O X-2$ promoter, a chromatin immunoprecipitation (ChIP) assay was performed to detect the association between the MBD proteins and the $C O X-2$ promoter. As shown in Supplementary Figure S1, there were no obvious changes in the binding activity of the methyl- $\mathrm{CpG}$ binding domain protein 1 (MBD1) or the methyl-CpG binding domain protein 2 (MBD2) to the $C O X-2$ promoter before or after TPA treatment. This result was consistent with the data obtained from a quantitative real-time PCR for the ChIP assay (ChIP-qPCR assay) (Supplementary Figure $\mathrm{S} 1)$. These results demonstrate that the reactivation of $C O X-2$ expression induced by TPA does not occur by altering the DNA methylation status of its promoter.

To investigate whether histone methylation is involved in the $C O X-2$ reactivation after TPA treatment, H719 cells were treated with $100 \mathrm{ng} / \mathrm{mL}$ of TPA for $6 \mathrm{hrs}$ and harvested to detect the histone methylation levels by Western blotting. We did not find obvious changes in several prominent histone methylations, such as $\mathrm{H} 3 \mathrm{~K} 4, \mathrm{H} 3 \mathrm{~K} 9$, H3K27, H3K 79 or H4K20, before or after TPA treatment (Supplementary Figure S2). Interestingly, we found that H3K36me2 was significantly decreased after TPA treatment 
A

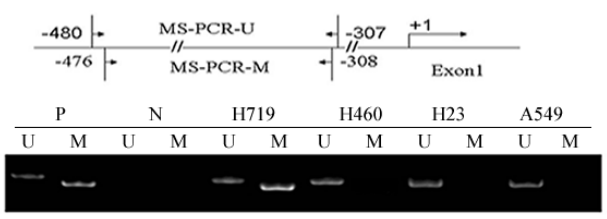

B

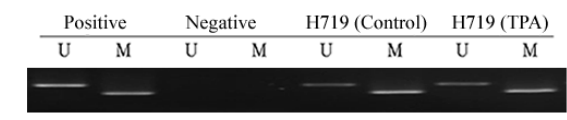

$\mathrm{E}$
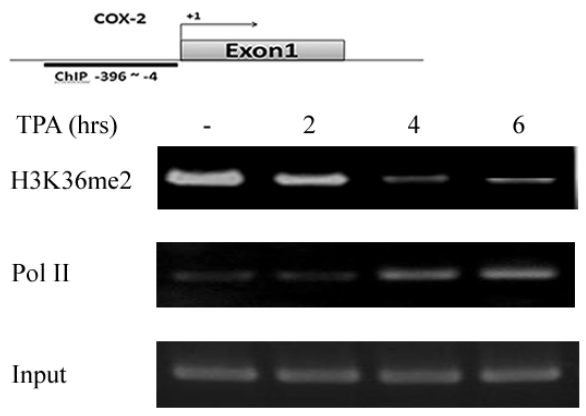

IgG
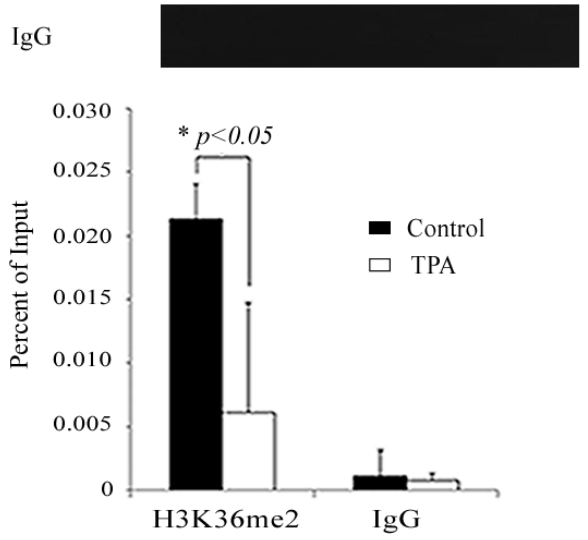

$\mathrm{C}$

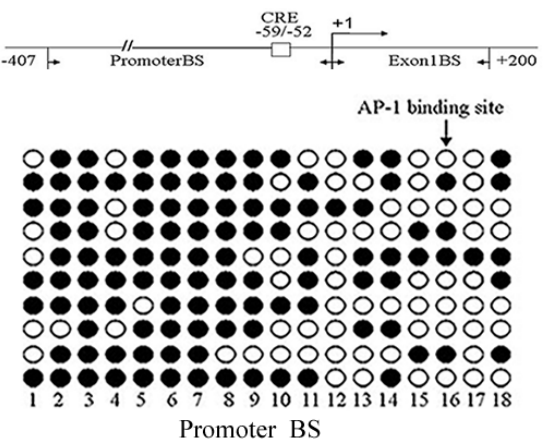

$\bullet \bullet \bullet \bullet \bullet \bullet \bullet \circ \bullet \bullet 0 \bullet 0000$

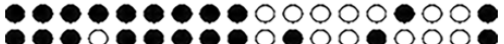

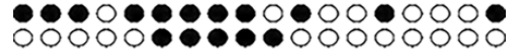
00006000000000000 -96996960909090900 009090999009090009

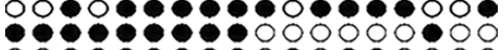

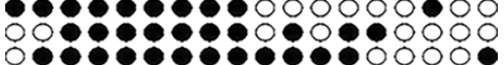

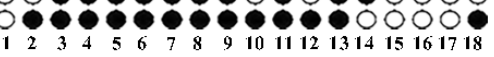
TPA Promoter BS

$\mathrm{D}$
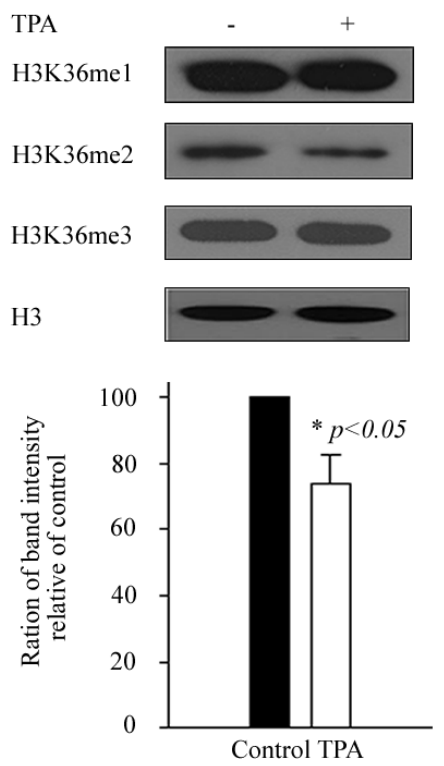

Figure 2: TPA reactivates $\mathrm{COX}-2$ expression without affecting the DNA methylation status of its promoter but associates with H3K36 methylation. A. DNA methylation status of the COX-2 promoter in $\mathrm{H} 719, \mathrm{H} 460, \mathrm{H} 23$ and $\mathrm{A} 549$ cells was detected by MSP. A schematic of the $C O X-2$ promoter and regions $(-480$ to $-307,-476$ to -308$)$ selected for DNA methylation detection. M indicates a methylated band and U indicates an unmethylated band. B. $\mathrm{H} 719$ cells were treated with TPA for 6 hrs at $100 \mathrm{ng} / \mathrm{mL}$, then MSP was used to detect the DNA methylation status of the $C O X-2$ promoter before and after TPA treatment. M indicates a methylated band and $\mathrm{U}$ indicates an unmethylated band. C. Bisulfite sequencing analysis of the COX-2 promoter, which contains $18 \mathrm{CpG}$ dinucleotides in $\mathrm{H} 719$ cells. A schematic of two regions, referred to as Promoter BS $(-407$ to +1$)$ and Exon1 BS $(+1$ to +200$)$, that were selected for bisulfate sequencing detection. AP-1 binding sites were labeled as CRE. More than ten independent clones of this cell line were sequenced. The promoter region showed 62.0\% (112 methylated at a total of 180 sites) and 60.6\% (109 methylated at a total of 180 sites) methylation before and after TPA treatment in $\mathrm{H} 719$ cells, respectively. Filled circle indicates methylated sites, and open circle indicates unmethylated sites. D. H719 cells were treated with $100 \mathrm{ng} / \mathrm{mL}$ TPA for $6 \mathrm{hrs}$, followed by Western blotting to determine the changes in H3K36 methylation patterns. H3 is shown as a loading control. $\mathrm{H} 3 \mathrm{~K} 36 \mathrm{me} 2$ bands were scanned, and the relative band intensities were normalized for each $\mathrm{H} 3$ band. The band intensity of the control was set as 100; the numerical value of the intensity of each band represents the percentage of the band intensity with respect to that of the control. The representative value in the lower column diagram is an average relative band intensity of H3K36me2, with standard error shown from three independent experiments. *, $p<0.05$. E. $\mathrm{H} 719$ cells were treated with TPA at $100 \mathrm{ng} / \mathrm{mL}$ for various intervals $(0,2,4$ and $6 \mathrm{hrs})$ and harvested for a ChIP assay to detect the enrichment of H3K36 me2 around the COX-2 promoter (the upper panel). The bands containing anti-IgG served as negative controls. ChIP-qPCR assay was also used to detect the changes in the enrichment of H3K36 me2 at the COX-2 promoter after 4 hrs of TPA treatment (the lower panel). *, $p<0.05$. 
in H719 cells (Figure 2D). To confirm the H3K36me2 changes upon TPA stimulation, the enrichment of the $\mathrm{H} 3 \mathrm{~K} 36 \mathrm{me} 2$ around the $\mathrm{COX}-2$ promoter was evaluated using a ChIP assay (Figure 2E). As shown in Figure 2E, H3K36me2 enrichment around the $\mathrm{COX}-2$ promoter was obviously decreased $4 \mathrm{hrs}$ after TPA treatment as demonstrated by ChIP and ChIP-qPCR assays. These results suggest that the changes in the H3K36me2 levels on the $C O X-2$ promoter may be associated with the transcriptional reactivation of the $C O X-2$ gene after TPA treatment.

\section{Lysine (K)-specific demethylase 2A (KDM2A) is involved in the TPA-induced reactivation of $\mathrm{COX}-2$}

We next searched for the enzymes that might be involved in the alteration of $\mathrm{H} 3 \mathrm{~K} 36 \mathrm{me} 2$ after TPA treatment. $\mathrm{H} 719$ cells were treated with $100 \mathrm{ng} / \mathrm{mL}$ of TPA for up to $6 \mathrm{hrs}$ and were harvested for Western blotting to detect the levels of H3K36me2 methyltransferases or demethylases. As shown in Figure 3A, the expression of the demethylases KDM2A (also called FBXL11) and KDM2B (also called NDY1) were not obviously changed after the TPA treatment. Additionally, the methyltransferases KMT3A (also called SETD2) and KMT3B (also called NSD1) and the demethylases KDM4A (also called JMJD2A) and KDM4B (also called JMJD2B) were also unchanged in TPA-treated cells (Supplementary Figure S3). Subsequently, a ChIP assay was used to detect the binding activity of histone methyltransferases or demethylases (for which an antibody was available) around the $C O X-2$ promoter upon TPA stimulation. As shown in Figure 3B, the KDM2A binding activity around the $C O X-2$ promoter was significantly increased in $\mathrm{H} 719$ cells and reached a peak at $4 \mathrm{hrs}$ after TPA treatment. These results indicate that KDM2A may play an important role in the TPA-induced reactivation of $C O X-2$ by down-regulating $\mathrm{H} 3 \mathrm{~K} 36 \mathrm{me} 2$ around the $C O X-2$ promoter. To further confirm the effect of KDM2A on $C O X-2$ reactivation, an empty vector or a Flag-KDM2A was transfected into H719 cells for $48 \mathrm{hrs}$, followed by treatment with TPA for $6 \mathrm{hrs}$ to detect the H3K36me 2 changes by Western blotting. As shown in Figure 3C, H3K36me2 was obviously decreased in the Flag-KDM2A-transfected H719 cells, and this decrease was more noticeable after TPA treatment. Moreover, the reactivation of $C O X-2$ was also more apparent in the FlagKDM2A-transfected H719 cells after TPA treatment. These data indicate the important role of KDM2A in the TPAinduced decrease of the $\mathrm{H} 3 \mathrm{~K} 36 \mathrm{me} 2$ and the reactivation of $C O X-2$ expression.

\section{c-Fos is required for the $\mathrm{H} 3 \mathrm{~K} 36 \mathrm{me} 2$ reduction around the $C O X-2$ promoter}

The main upstream transcriptional factors of $C O X-2$, such as AP-1, p300/CBP and NF- $\mathrm{BB}$, can be activated by a series of kinase reactions after certain types of stimulation and can thus induce the expression of $C O X-2[9,10]$. To explore the effect of the related transcription factors on $C O X$-2 re-expression during TPA treatment, $\mathrm{H} 719$ cells were treated with TPA at $100 \mathrm{ng} / \mathrm{mL}$ for up to $6 \mathrm{hrs}$ and then harvested to detect the expression of these transcriptional factors with Western blotting. As shown in Figure 4A, the protein levels of $\mathrm{p} 300, \mathrm{NF}-\kappa \mathrm{B}$ and CEBP $\beta$ were not changed after TPA treatment, but the expression of c-Fos and c-Jun, both main dimer units of AP-1, increased significantly in H719 cells. The c-Fos protein levels were increased significantly and reached a peak at 2 hrs after TPA treatment (Figure 4A). In addition, a qPCR was performed to detect FOS mRNA levels in $\mathrm{H} 719$ cells. The FOS mRNA levels also increased significantly and reached a peak at $2 \mathrm{hrs}$ after TPA treatment in H719 cells (Figure 4B). To further clarify the effect of c-Fos on the expression of $C O X-2$, a ChIP assay was performed to detect c-Fos binding activity around the $C O X-2$ promoter. As shown in Figure 4C, c-Fos binding activity around the $C O X-2$ promoter increased dramatically after TPA treatment in H719 cells. In addition, the binding activity of c-Jun around the $C O X-2$ promoter failed to be detected, which indicates that c-Jun may not be involved in the $\mathrm{COX}$-2 reactivation in $\mathrm{H} 719$ cells (Figure 4C). To confirm whether c-Fos is required for the reactivation of $C O X-2, \mathrm{H} 719$ cells were transiently transfected with a siRNA against $F O S$ or a non-specific siRNA and then treated with TPA. Cells were harvested and subjected to RTPCR or a ChIP assay. As shown in Figure 4D, the expression of FOS induced by TPA significantly decreased in cells transfected with c-Fos siRNA compared with that in the cells transfected with the non-specific siRNA. In addition, the decreased $\mathrm{H} 3 \mathrm{~K} 36 \mathrm{me} 2$ around the $C O X-2$ promoter was almost completely reversed after TPA treatment in the H719 cells with FOS expression knockdowned by c-Fos siRNA (Figure 4E). Additionally, the enriched $\mathrm{H} 3 \mathrm{~K} 36 \mathrm{me} 2$ at the $C O X-2$ promoter was decreased by $75.0 \%$ in the non-specific siRNA-transfected $\mathrm{H} 719$ cells, whereas the changes in $\mathrm{H} 3 \mathrm{~K} 36 \mathrm{me} 2$ at the $C O X$ 2 promoter were largely reversed when $F O S$ was knocked down by c-Fos siRNA, as demonstrated by ChIP-qPCR assay (Figure 4E). These data indicate that c-Fos is indispensable for the histone $\mathrm{H} 3 \mathrm{~K} 36 \mathrm{me} 2$ down-regulation at the $C O X-2$ promoter and for the reactivation of the expression of $C O X-2$ after TPA treatment.

\section{c-Fos interacts with KDM2A in vitro and in vivo}

To explore the mechanism by which c-Fos regulates $\mathrm{H} 3 \mathrm{~K} 36 \mathrm{me} 2$ reduction and its role in the reactivation of $C O X-2$ after TPA treatment in lung cancer cells, several demethylases that are involved in histone H3K36me2 demethylation were investigated by Co-IP (Figure 5A). A Myc-tagged c-Fos and Flag-tagged demethylases, including KDM2A, KDM4A and KDM4B, were cotransfected into HEK293T cells, and the interaction between c-Fos and each of these H3K36 demethylases was assessed. As shown in Figure 5A, KDM2A interacted with c-Fos, which implies that KDM2A may be the 

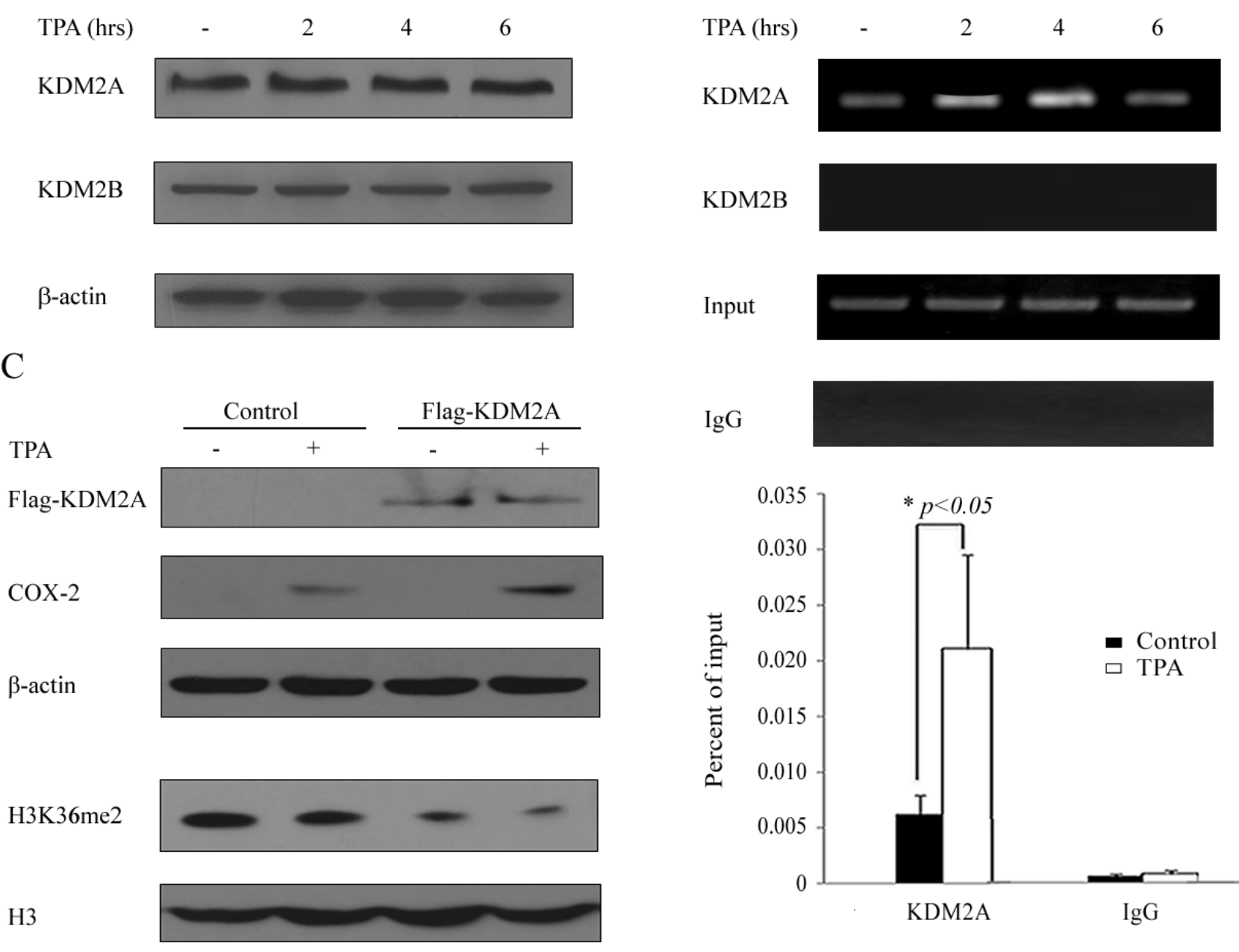

Input

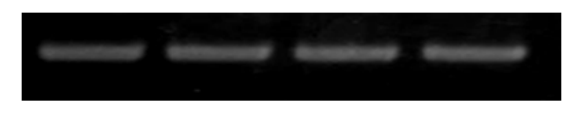

$\operatorname{IgG}$
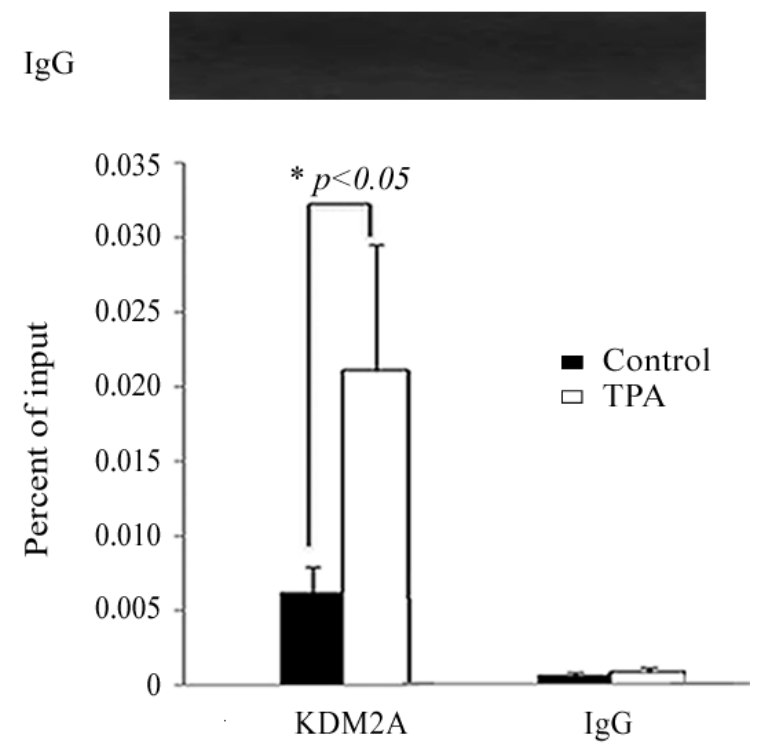

Figure 3: Lysine (K)-specific demethylase 2A (KDM2A) is involved in the TPA-induced reactivation of the COX-2 gene. A. H719 cells were treated with TPA at $100 \mathrm{ng} / \mathrm{mL}$ for various intervals (0, 2, 4 and $6 \mathrm{hrs})$, and then the cells were harvested for Western blotting to assess the expression of demethylases KDM2A and KDM2B. $\beta$-actin was used as a loading control. B. H719 cells were treated as outlined above and harvested for a ChIP assay to detect the binding activity of KDM2A and KDM2B around the $C O X-2$ promoter (the upper panel). The bands with anti-IgG served as negative controls. ChIP-qPCR assay was used to detect the binding activity changes of KDM2A around the COX-2 promoter after $4 \mathrm{hrs}$ of TPA treatment (the lower panel). ${ }^{*}, p<0.05$. C. H719 cells were transfected with empty vector or with a Flag-KDM2A plasmid for $48 \mathrm{hrs}$ and then treated with TPA for $6 \mathrm{hrs}$. The cells were harvested for Western blotting to detect the expression of $\mathrm{COX}-2$ and $\mathrm{H} 3 \mathrm{~K} 36 \mathrm{me} 2$. $\beta$-actin and $\mathrm{H} 3$ were each used as loading controls.

co-activator of c-Fos in the mediation of $C O X-2$ reactivation after TPA treatment. To confirm this result, a His-tagged c-Fos protein was expressed in bacteria, purified and incubated with GST and GST-KDM2A to investigate whether KDM2A directly interacted with c-Fos. As shown in Figure 5B, c-Fos showed direct interactions with GST-KDM2A but not with GST alone. To further map the regions of c-Fos responsible for its interaction with KDM2A, fragments representing full length (FL), N-terminal (aa 1-136), middle (aa 137-200) and C-terminal (aa 201-381) versions of c-Fos as shown in Figure $5 \mathrm{C}$ were expressed, purified and incubated with a GST-KDM2A. As shown in Figure 5D, GST-KDM2A specifically interacted with the FL and middle region fragment of c-Fos, showing that KDM2A can directly interact with c-Fos in vitro. Next, we explored the effect of the interaction between KDM2A and c-Fos after TPA stimulation. $\mathrm{H} 719$ cells were treated with or without TPA for $2 \mathrm{hrs}$, and the cells were then harvested to detect the endogenous interaction between KDM2A and c-Fos by Co-IP. As shown in Figure 5E and 5F, the interaction of KDM2A and c-Fos significantly increased after TPA treatment in H719 cells compared with the non-TPA treated control. Also, the similar result was found in H460 cells (Supplementary Figure S4F). In addition, a fluorescence resonance energy transfer (FRET) assay by fluorescence lifetime imaging (FLIM) was performed to confirm the interaction of KDM2A and c-Fos in response to TPA treatment. HEK293T cells were transfected with pECFP-c-Fos and/or pEYFP-KDM2A plasmids, followed 
A
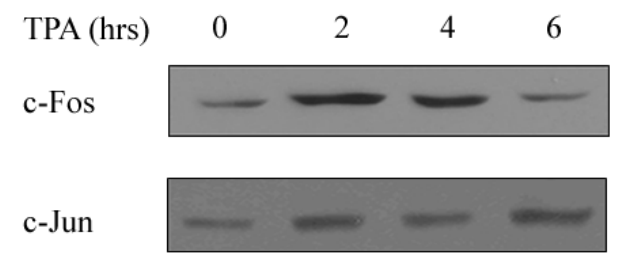

p300

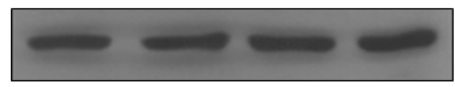

$\mathrm{NF}-\mathrm{KB}$

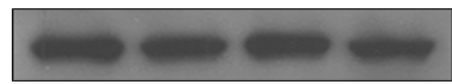

CEBP $\beta$

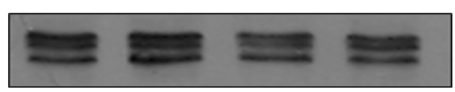

$\beta$-actin

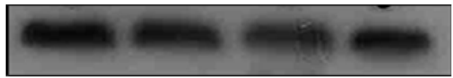

B

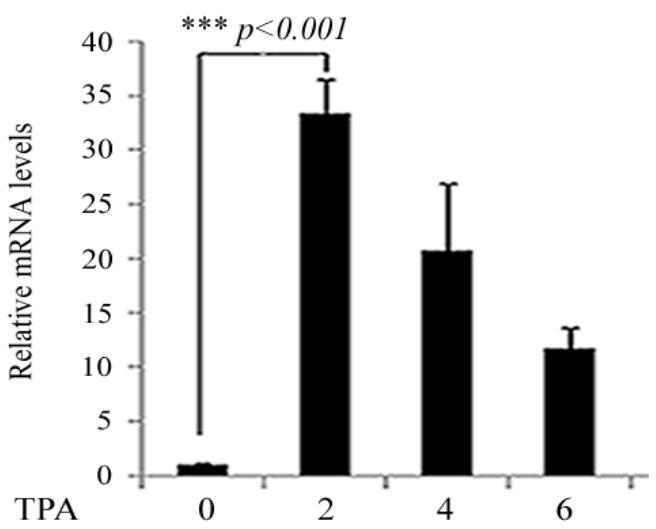

C

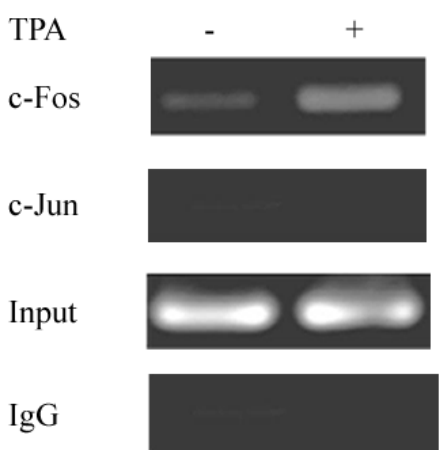

$\mathrm{D}$

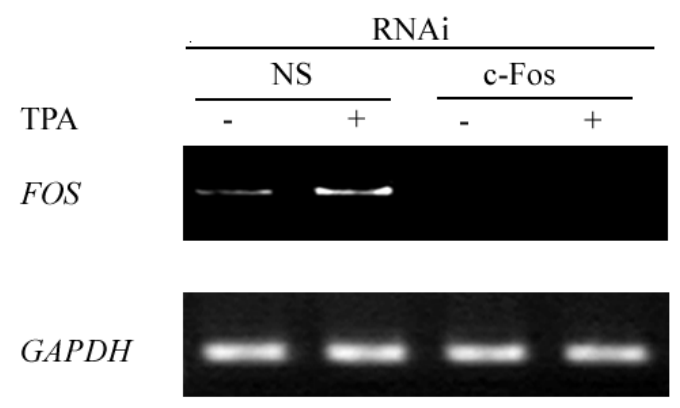

E

TPA

H3K36me2

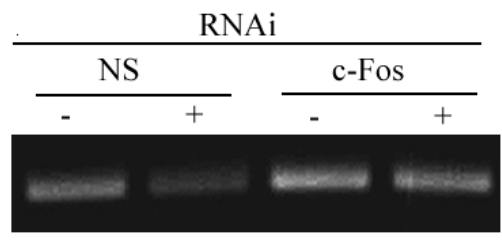

Input

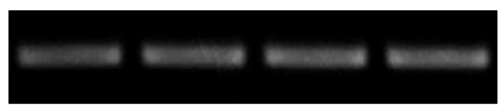

IgG
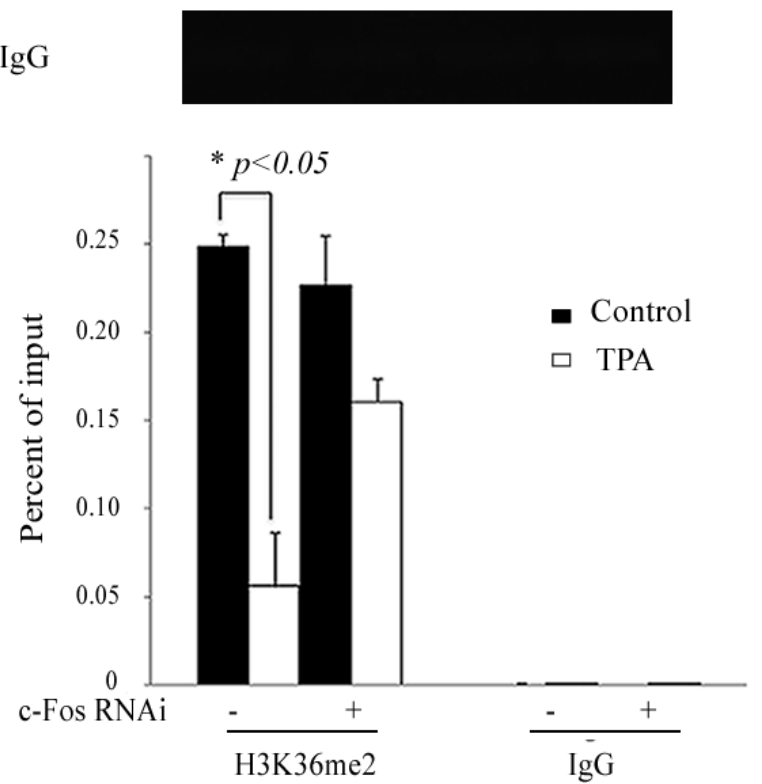

Figure 4: The upregulation of c-Fos is responsible for H3K36me2 reduction around the $C O X-2$ promoter by TPA treatment. A. H719 cells were treated with TPA at $100 \mathrm{ng} / \mathrm{mL}$ for various intervals $(0,2,4$ and $6 \mathrm{hrs})$, and the cells were then harvested for Western blotting to detect the expression of c-Fos, c-Jun, p300, NF- $\kappa$ B and CEBP $\beta$. $\beta$-actin was used as a loading control. B. H719 cells were treated as outlined above, and the expression of FOS on mRNA levels was confirmed by real-time PCR. ***, $p<0.001$. C. H719 cells were treated with TPA at $100 \mathrm{ng} / \mathrm{mL}$ for $2 \mathrm{hrs}$ and then harvested for a ChIP assay to detect the binding activity of c-Fos or c-Jun near the COX-2 promoter. The bands with anti-IgG served as negative controls. D. H719 cells were transfected with c-Fos siRNA and non-specific siRNA (NS) for $24 \mathrm{hrs}$ and then treated with TPA for $2 \mathrm{hrs}$ at $100 \mathrm{ng} / \mathrm{mL}$. RT-PCR was performed to detect FOS mRNA expression. GAPDH was used as a loading control. E. H719 cells were treated with TPA at $100 \mathrm{ng} / \mathrm{mL}$ for $4 \mathrm{hrs}$ and harvested for a ChIP assay to detect the enrichment of H3K36me2 around the COX-2 promoter (the upper panel). The bands with anti-IgG served as negative controls. ChIP-qPCR assay was used to detect the change of $\mathrm{H} 3 \mathrm{~K} 36 \mathrm{me} 2$ at the $C O X-2$ promoter after 4 hrs of TPA treatment (the lower panel). $*, p<0.05$. 
A

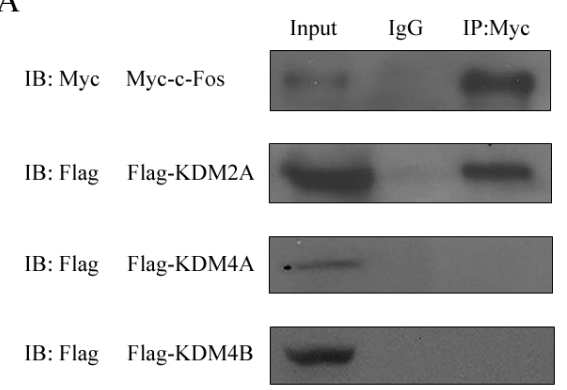

$\mathrm{D}$

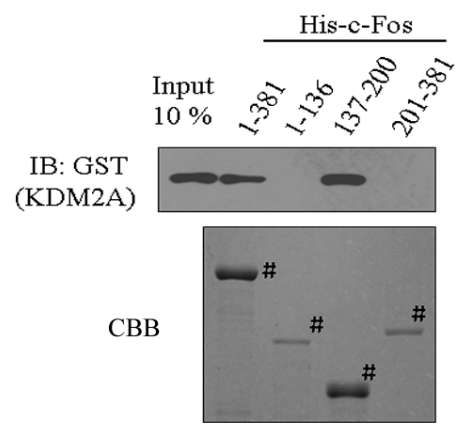

G
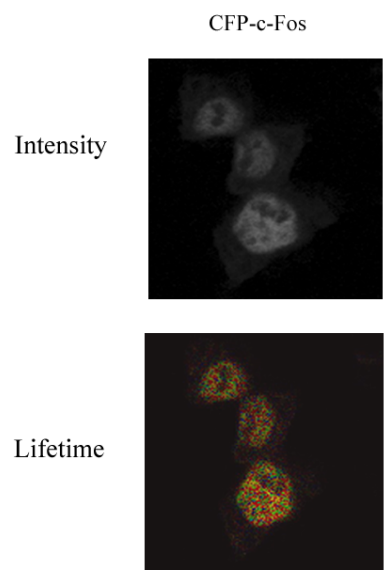

B

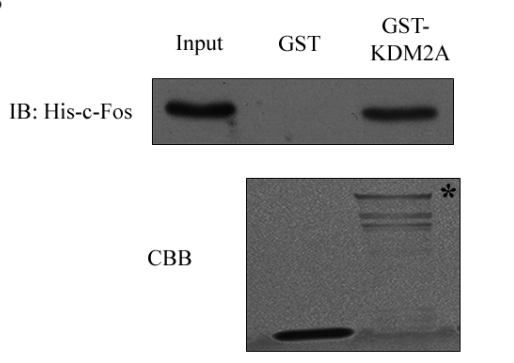

$\mathrm{E}$

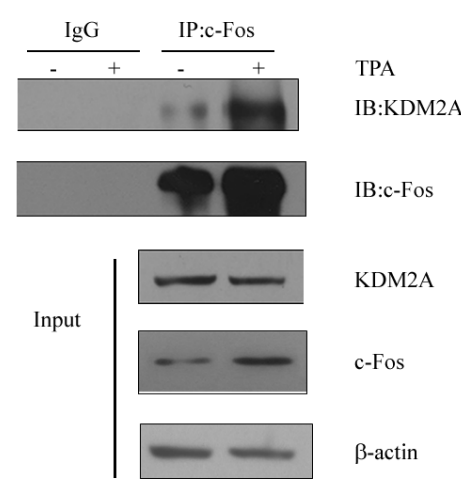

$\mathrm{F}$
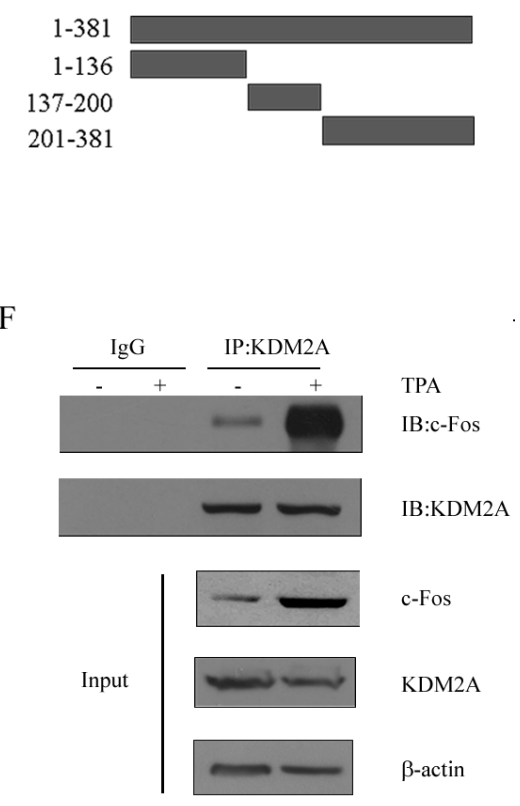

$\mathrm{C}$

$\mathrm{H}$

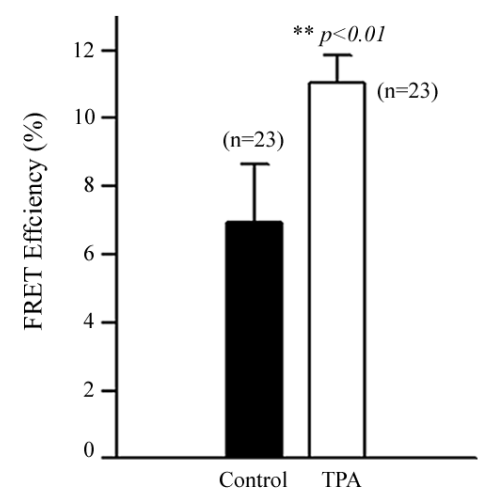

Figure 5: c-Fos interacts with KDM2A in vitro and in vivo. A. A Myc-tagged c-Fos and a Flag-tagged histone modification enzyme (as indicated in the figure) were co-transfected into HEK293T cells and the proteins were then extracted for Co-IP with anti-Myc and anti-Flag antibodies, followed by immunoblotting with anti-Myc. B. GST-KDM2A was incubated with His-c-Fos, and Western blotting or Coomassie staining was performed to detect the direct binding of c-Fos and KDM2A in vitro. * indicates the specific bands. C. Schematic of plasmids encoding full-length c-Fos, an N-terminal fragment (aa 1-136), a middle fragment (aa 137-200) and a C-terminal fragment (aa 201-381). D. His-c-Fos FL or fragments were incubated with GST-KDM2A, and Western blotting with an anti-GST antibody or Coomassie staining was performed to detect the interaction. \# indicates the specific bands. E. H719 cells were treated without or with TPA for $2 \mathrm{hrs}$ at $100 \mathrm{ng} / \mathrm{mL}$, then the cell were extracted for Co-IP using an anti-c-Fos antibody, followed by Western blotting using anti-KDM2A or anti-c-Fos antibodies to detect the interaction between c-Fos and KDM2A. F. H719 cells were treated without or with TPA for 2 hrs at $100 \mathrm{ng} / \mathrm{mL}$, then the cells were extracted for Co-IP using anti-KDM2A antibody, followed by Western blotting using an anti-KDM2A or anti-c-Fos antibodies to detect the interaction between c-Fos and KDM2A. G. HEK293T cells were transfected with pECFP-c-Fos and/or pEYFP-KDM2A plasmids, followed by TPA treatment for $2 \mathrm{hrs}$. FLIM assays were performed, and the images of representative cells are shown for each group. H. FRET efficiency is shown in the column diagram, and the representative value is an average FRET efficiency of 23 cells with standard error. **, $p<0.01$.

by TPA treatment for $2 \mathrm{hrs}$. The donor lifetime (CFP-cFos) was shortened in the TPA treatment group compared with the control group (Figure 5G). Statistically, the energy transfer efficiency was obviously increased after TPA treatment in HEK293T cells compared with that in untreated cells, demonstrating that the interaction between KDM2A and c-Fos was increased in response to TPA treatment (Figure 5H). Taken together, this suggests that KDM2A directly interacts with c-Fos and that the increased interaction between KDM2A and c-Fos after TPA treatment plays a critical role in the reactivation of the $C O X-2$ gene expression. 
A

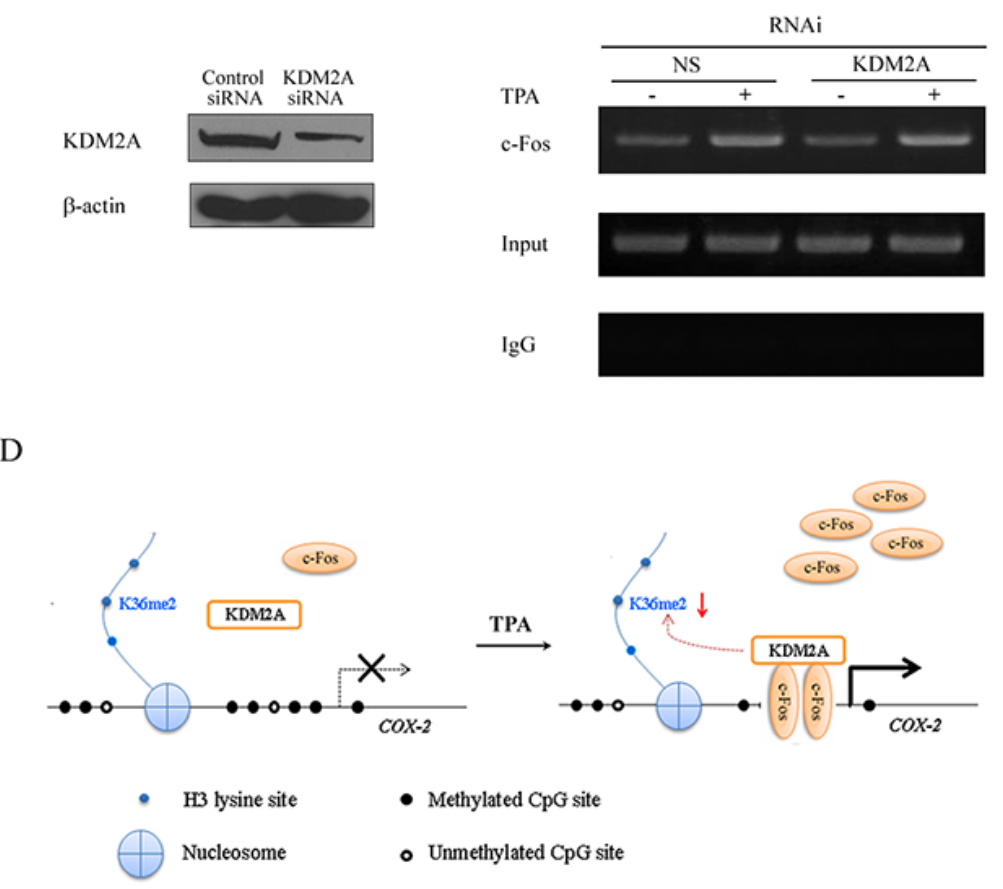

C
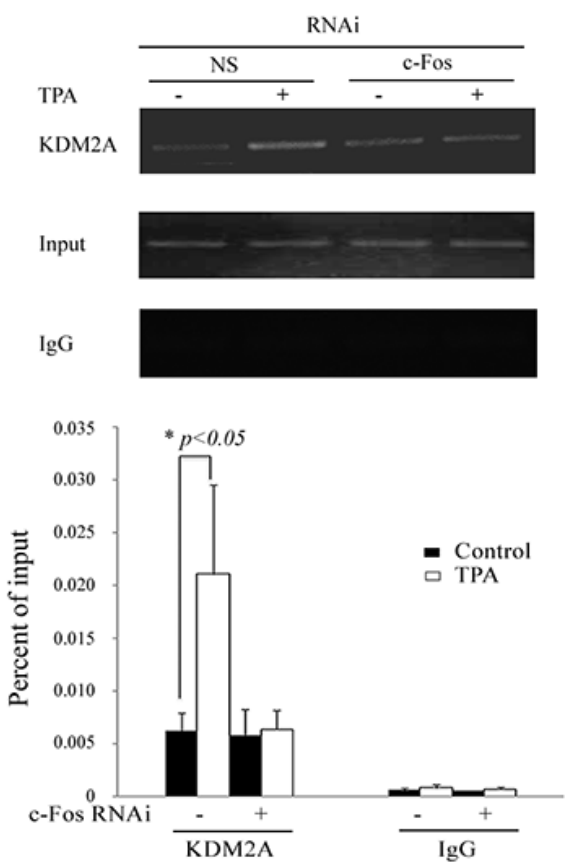

Figure 6: c-Fos recruits KDM2A to the $\boldsymbol{C O X}$-2 promoter. A. H719 cells were transfected with KDM2A siRNA or non-specific siRNA (NS) for $48 \mathrm{hrs}$, followed by Western blotting to assess the efficiency of the RNAi. B. H719 cells were transfected with KDM2A siRNA or non-specific siRNA (NS) for $48 \mathrm{hrs}$ and treated with TPA at $100 \mathrm{ng} / \mathrm{mL}$ for $2 \mathrm{hrs}$. A ChIP assay was performed to detect the binding activity of c-Fos around the $C O X-2$ promoter. The bands containing anti-IgG served as negative controls. C. H719 cells were transfected with c-Fos siRNA or non-specific siRNA (NS) for $48 \mathrm{hrs}$ and then treated with TPA for $4 \mathrm{hrs}$ at $100 \mathrm{ng} / \mathrm{mL}$. A ChIP assay was performed to detect the binding activity of KDM2A around the $C O X-2$ promoter (the upper panel). ChIP-qPCR assay was used to detect the change in binding activity of KDM2A around the $C O X-2$ promoter after $4 \mathrm{hrs}$ of TPA treatment (the lower panel). ${ }^{*}, p<0.05$. D. A schematic showing a possible mechanism by which TPA induces the methylated $C O X-2$ gene re-expression. All symbols are defined in the diagram.

\section{c-Fos recruits KDM2A to the $C O X-2$ promoter}

To explore the effect of the interaction between KDM2A and c-Fos in cancer cells after TPA treatment, KDM2A expression was down-regulated by KDM2A siRNA (Figure 6A) to test the binding activity of c-Fos to the $\mathrm{COX}-2$ promoter. H719 cells were treated with TPA after transient transfection with KDM2A siRNA or a non-specific siRNA for $48 \mathrm{hrs}$, and the cells were then harvested and subjected to a ChIP assay. As shown in Figure 6B, c-Fos was enriched on the $C O X-2$ promoter by TPA treatment, which was not dependent on the presence of KDM2A. By contrast, the enrichment of KDM2A around the $C O X-2$ promoter was significantly reduced when $F O S$ was knockdowned. As shown in Figure 6C, the enrichment of KDM2A around the COX-2 promoter in non-specific siRNA-transfected cells was significantly increased after TPA treatment compared with that in the c-Fos siRNA-transfected $\mathrm{H} 719$ cells. The enrichment of KDM2A around the $C O X-2$ promoter was reduced by $71.0 \%$ after TPA treatment in c-Fos siRNA-transfected cells compared with that in the non-specific siRNA-transfected H719 cells, as assayed by ChIP-qPCR (Figure 6C). These results indicate that c-Fos reactivates $C O X-2$ expression by recruiting $\mathrm{KDM} 2 \mathrm{~A}$ to the $C O X-2$ promoter, which in turn decreases $\mathrm{H} 3 \mathrm{~K} 36 \mathrm{me} 2$ around the $\mathrm{COX}-2$ promoter.

\section{DISCUSSION}

In this study, our data reveal a novel mechanism by which the carcinogen TPA activates the expression of $C O X-2$ in human lung cancer cells. Histone demethylation at $\mathrm{H} 3 \mathrm{~K} 36 \mathrm{me} 2$, but not DNA demethylation around the promoter of $C O X-2$, is critical for the TPA-induced reactivation of $C O X-2$. In addition, the transcription factor c-Fos plays an important role in the TPA-mediated reduction of histone $\mathrm{H} 3 \mathrm{~K} 36$ dimethylation by recruiting the H3K36 demethylase KDM2A onto the $C O X-2$ promoter.

Epigenetic mechanisms are involved in the response to a variety of environmental carcinogen exposures, yet the exact mechanisms underlying this effect are not well understood. Aberrant DNA methylation of the $\mathrm{COX}-2$ CpG islands was first reported in colorectal tumors [31], and DNA hypermethylation of $\mathrm{COX}-2$ at its promoter was shown to be related to $C O X-2$ gene silencing [20, 21]. However, in this study, DNA methylation was not changed before or after TPA treatment, showing that TPA-induced $C O X-2$ gene re-expression is independent of DNA methylation (Figure 2B). This finding is not so surprising, considering that TPA is not a demethylation agent, such as 5-aza-2'-deoxycytidine. When H719 cells were treated with 
5-aza-2'-deoxycytidine, $C O X-2$ expression was reactivated in a DNA methylation-dependent manner (Supplementary Figure S5A and S5B). Also, the enrichment of H3K36me2 around the $C O X-2$ promoter was obviously decreased after 5-aza-2'-deoxycytidine treatment as detected by ChIPqPCR assay, suggesting that $\mathrm{H} 3 \mathrm{~K} 36 \mathrm{me} 2$ demethylation around the $C O X-2$ promoter plays some role in $C O X-2$ re-expression in $\mathrm{H} 719$ cells (Supplementary Figure S5C). However, whether the re-expression of $C O X$-2 after 5-aza2 -deoxycytidine treatment is exclusively due to histone demethylation or DNA demethylation needs further exploration. The re-expression of $C O X-2$ induced by TPA or 5-aza-2'-deoxycytidine may occur through different mechanisms, and TPA reactivates $C O X-2$ mainly by a c-Fos- and KDM2A-mediated decrease of H3K36me2.

In addition to DNA methylation, histone modification is a critical epigenetic regulator that helps control chromatin structure and gene regulation [32]. Among histone modifications, histone methylation-mediated gene regulation has been well studied $[32,33]$. The histone methylation of $\mathrm{H} 3 \mathrm{~K} 4$ and $\mathrm{H} 3 \mathrm{~K} 79$ plays a role in activating gene expression, whereas the methylation of $\mathrm{H} 3 \mathrm{~K} 9$ and $\mathrm{H} 3 \mathrm{~K} 27$ has been suggested to be a gene repressor in euchromatin [15, 32]. H3K36 methylation was reported to play dual functions in gene expression; studies in multiple systems have supported a role for $\mathrm{H} 3 \mathrm{~K} 36$ methylation in transcriptional activation [34, 35]. The levels and spatial distribution of di- and tri-H3K36 methylation in several genes have been analyzed, which showed that the active genes contain high levels of di- and tri- H3K36 methylation in actively transcribed regions [34]. Human epigenetic analysis also showed that the gene bodies of actively transcribed genes are associated with $\mathrm{H} 3 \mathrm{~K} 36 \mathrm{me} 3$ [35]. By contrast, the effect of H3K36 methylation on transcriptional repression has also been reported [27, 3638]. Set2 is a histone methyltransferase (HMT) that is sitespecific for lysine 36 (Lys36) in the H3 tail. Set2 represses the basal expression of GAL4 in Saccharomyces cerevisiae by mediating the methylation form of H3K36 [36]. H3K36me2 has been reported to recruit histone demethylase complex $\operatorname{Rpd} 3 \mathrm{~s}$, which is one of the strong gene repression factors that represses spurious transcription [37]. In addition, the epigenetic inactivation of the histone methyltransferase NSD1 leads to the specifically diminished methylation of the histone lysine residues H3K36 and increases the expression of oncogene MEIS1 in human neuroblastoma and glioma [38]. In our study, we found that H3K36me2 was reduced both in the promoter and the transcribed regions of the $C O X-2$ gene, indicating that $\mathrm{H} 3 \mathrm{~K} 36 \mathrm{me} 2$ might play an important role in gene repression by mediating the transcriptional reactivation of $C O X-2$ in human lung cancer cells (Figure 2D and 2E, Supplementary Figure S4A and S4B, and Supplementary Figure S6A and S6B). In addition, the changes of $\mathrm{H} 3 \mathrm{~K} 36 \mathrm{me} 3$ in the transcribed region of the $C O X-2$ gene were detected by ChIP-qPCR assay, and no significant increased $\mathrm{H} 3 \mathrm{~K} 36 \mathrm{me} 3$ enrichment was found in each exon of the $C O X-2$ gene, suggesting that $\mathrm{H} 3 \mathrm{~K} 36 \mathrm{me} 3$ is not related to the increased expression of $C O X-2$ in response to TPA treatment (Supplementary Figure S6C). Thus, H3K36 methylation appears to act as both an activating and an inhibitory signal, and the overall biological readout may depend on the context of the additional surrounding markers and their corresponding reader proteins.

H3K36 is methylated by lysine methyltransferases and demethylated by lysine demethylases, including KDM2A [28, 39]. KDM2A is a JmjC-containing histone demethylase that targets mono- and dimethylated Lys36 on $\mathrm{H} 3$ residues. In lung cancer, KDM2A was reported to be a novel oncogenic promoter of non-small cell lung cancer (NSCLC), and the overexpression of KDM2A was shown to promote tumorigenicity and metastasis by epigenetically enhancing ERK1/2 signaling in NSCLC [40]. KDM2A expression was found to be increased in gastric cancer tissues, and KDM2A may regulate the growth and motility of gastric cancer cells by down-regulating the expression of tumor suppressor programmed cell death 4 (PDCD4) in the progression of gastric cancer [41]. Conversely, KDM2A was found to regulate $\mathrm{E} 2 \mathrm{~F} 1$-mediated gene transcription and thus to suppress the invasion and migration in breast cancer cells [42]. Silencing KDM2A using small interfering RNAs increased the invasion and migration of breast cancer cells by suppressing a subset of matrix metalloproteinases, such as MMP-2, MMP-9, MMP-4 and MMP-15 [42]. In our study, the enrichment of KDM2A around the $C O X-2$ promoter was significantly increased after TPA treatment, which indicates that KDM2A is involved in the TPAinduced reactivation of the $C O X-2$ gene (Figure $3 \mathrm{~B}$ and $3 \mathrm{C}$ ). KDM2A may reactivate the expression of $\mathrm{COX}-2$ gene by decreasing $\mathrm{H} 3 \mathrm{~K} 36 \mathrm{me} 2$ near the $C O X-2$ promoter in human lung cancer cells.

Chromatin-modifying enzymes function as cofactors and are frequently recruited by transcription factors to chromatin to activate or repress gene expression. Our data show that c-Fos was indispensable for histone $\mathrm{H} 3 \mathrm{~K} 36 \mathrm{me} 2$ changes at the $C O X-2$ promoter by recruiting $\mathrm{KDM} 2 \mathrm{~A}$ to the $C O X-2$ promoter and reactivating $C O X-2$ expression after TPA treatment in both $\mathrm{H} 719$ and $\mathrm{H} 460$ cells (Figure 4-6 and Supplementary Figure S4C-S4G). The effects of c-Fos on histone modification have also been found in the regulation of other genes [43, 44]. c-Fos induced SIRT6 transcription, which repressed survivin by reducing histone $\mathrm{H} 3 \mathrm{~K} 9$ acetylation and $\mathrm{NF}-\kappa \mathrm{B}$ activation [43]. Oxidized low-density lipoprotein (oxLDL), which is a major risk factor for cardiovascular disease, could effectively increase the expression of microRNA-29b through the activation of c-Fos expression. Decreased methylation at $\mathrm{H} 3 \mathrm{~K} 9$ in response to oxLDL was significantly abolished in the absence of c-Fos, which implies that oxLDL-mediated histone modifications are mediated through the activation of c-Fos, which eventually causes miR-29b up-regulation [44]. These results are similar to our data showing that c-Fos is an important transcription factor for gene regulation through mediating histone modification. Also, several co-downstreams of 
both COX-2 and c-Fos were identified after TPA treatment in H460 cells. The expression of $m P G E S-1$ and EP2 is significantly increased in a dose-dependent manner after TPA treatment, which is similar with the pattern of $C O X-2$ expression under the same conditions. These data suggest that the COX-2-mPGES-1-EP2 pathway was activated in response to TPA treatment (Supplementary Figure S7A). Among the downstreams of c-Fos, we found that the expression pattern of VEGF was same as the expression pattern of c-FOS, while an opposite expression pattern was found in the expression of p27 after TPA stimulation (Supplementary Figure S7B). Interestingly, the expression of $M M P 1$ was constantly increased in a dose-dependent manner after TPA treatment, suggesting that MMP1 may be another gene activated by TPA through c-Fos.

To our knowledge, this is the first report showing that transcription factor c-Fos mediates the TPA-induced $C O X-2$ reactivation by recruiting $\mathrm{KDM} 2 \mathrm{~A}$ to the $C O X-2$ promoter in human lung cancer cells. Based on the above observations, we propose a mechanism to explain the effect of TPA on $C O X-2$ gene reactivation (Figure 6D). TPA directly induces the expression of c-Fos and thus enriches c-Fos around the $C O X-2$ promoter. Subsequently, c-Fos recruits KDM2A to the $C O X-2$ promoter, which further decreases the $\mathrm{H} 3 \mathrm{~K} 36 \mathrm{me} 2$ levels on the $C O X-2$ promoter. Consequently, $C O X-2$ is reactivated by TPA. Our data suggest a novel mechanism by which TPA activates the expression of $C O X-2$ and provide a new target for designing anti-cancer strategies and preventing lung cancer development.

\section{MATERIALS AND METHODS}

\section{Cell culture and chemical treatment}

Human lung cancer cell lines H719, H460, H23 and A549 were purchased from American Type Culture Collection (ATCC, Manassas, VA). H460 and H23 cells were cultured in RPMI-1640 medium supplemented with $10 \%$ heat-inactivated fetal bovine serum (FBS). H719 cells were cultured in DMEM: F12 medium with 5\% heat-inactivated FBS. A549 cells were cultured in F-12K medium with $10 \%$ heat-inactivated FBS. All the cells were cultured in the medium mentioned above with penicillin/ streptomycin in a $37^{\circ} \mathrm{C}$ incubator with a humidified, $5 \%$ $\mathrm{CO} 2$ atmosphere. All cells obtained from ATCC were immediately expanded and frozen down for future use (every 3 months from a frozen vial) of the same batch of cells. Chemical reagents 12-O-tetradecanoylphorbol13-acetate (TPA) was purchased from Sigma (St Louis, MO, USA). TPA (dissolved in DMSO) was fresh added in medium and then incubated at $37^{\circ} \mathrm{C}$ for various time intervals. Control cells were treated with dimethyl sulfoxide for similar time intervals. The final concentration of added DMSO was lower than $0.1 \%(\mathrm{~V} / \mathrm{V})$.

\section{Methylation-specific PCR}

DNA was extracted and then treated with bisulfite as previously described with minor modifications [45]. Briefly, genomic DNA $(1 \mu \mathrm{g})$ in a volume of $50 \mu \mathrm{l}$ was denatured with $\mathrm{NaOH}$ (final concentration, $0.275 \mathrm{M}$ ) for $10 \mathrm{~min}$ at $42^{\circ} \mathrm{C}$. The denatured DNA was then treated with $10 \mu \mathrm{l}$ of $10 \mathrm{mM}$ hydroquinone and $520 \mu \mathrm{l}$ of $3 \mathrm{M}$ sodium bisulphate at $50^{\circ} \mathrm{C}$ overnight. The MSP primers for $C O X-2$ were as follows: Methylated forward primer, 5'-CGT ATA GAT TAG ATA CGG C -3' and methylated reverse primer, 5'-TTT ACC CGA ACG CTT CCG AA-3'; Unmethylated forward primer, 5'-AAG ATG TAT AGA TTA GAT ATG GT-3'and unmethylated reverse primer, 5'-CTT TAC CCA AAC ACT TCC AAA-3'. The PCR products were then size fractionated by using a $2 \%$ agarose gel, stained with ethidium bromide, and evaluated with UV light.

\section{Bisulfite sequencing}

DNA was treated with bisulfite and purified for PCR as described previously [45]. The primers for $C O X$ 2 sequencing were as follows: Forward primer 1, 5'-TTT GGA GAG GAA GTT AAG TG -3' and reverse primer 1, 5'- CTC TCC CCT TAA AAA AAT TA-3'; Forward primer 2, 5'-AAG GGG AGA GGA GGG AAA AA-3' and reverse primer 2, 5'- CGC CAA ATA CTC ACC TAT AT-3'. The PCR products were gel extracted with a Qiaquick gel extraction kit (Qiagen, Valencia, CA) and ligated into the pGEM-T easy vector by using the TA cloning system (Invitrogen, Carlsbad, CA). Ttransformed Escherichia coli DH5 $\alpha$ cells were cultured overnight, and the plasmid DNA was isolated using a kit (Qiagen,Valencia, CA). At least 10 separate clones were chosen for sequence analysis.

\section{Chromatin immunoprecipitation (ChIP) assay}

A chromatin immunoprecipitation (ChIP) assay was performed as described previously [46]. Briefly, $2 \times 10^{7}$ cells treated with TPA were fixed with $1 \%$ formaldehyde at $37^{\circ} \mathrm{C}$ for $10 \mathrm{~min}$ and were then lysed on ice for $15 \mathrm{~min}$. These lysed extracts were subjected to shearing by sonication. The soluble chromatin was subjected to immunoprecipitation with antibodies against different modified histones and other proteins as indicated. The primers for all ChIPs are available upon request.

\section{RNA interfence (RNAi)}

RNA interference was performed as mentioned [47]. The sequences of RNA interference (RNAi) oligonucleotides for controls (non-specific) and c-Fos were as follows: non-specific siRNA, TTC TCC GAA CGT GTC ACG T; c-Fos siRNA, CAT CTG TGA ATG ATA ATT. These RNAi oligonucleotides were transfected into H719 and H460 cells by using the Lipofectamine 
2000 transfection kit (Invitrogen, Carlsbad, CA) according to the manufacturer's instructions. Cells were harvested after 48 hours of transfection and subjected to Western blotting and a ChIP assay, respectively.

\section{Histone extraction, total protein extraction and western blotting}

To identify histone modifications, acid extraction of histone was performed as previously reported [48]. To detect other proteins, cells were extracted with lysis buffer (50 mM Tris-HCl, $250 \mathrm{mM} \mathrm{NaCl}, 5 \mathrm{mM}$ EDTA, $50 \mathrm{mM} \mathrm{NaF}, 1.5 \mathrm{mM}$ PMSF and protease inhibitors cocktail). Equal amounts of protein were size fractionated on 6.0 to $15.0 \%$ SDS-PAGE gel. The antibodies used were anti-COX-2 (sc-19999, Santa Cruz), anti-c-Fos (ab7963, Abcam), anti-c-Jun (sc-44, Santa Cruz), antiKMT3A (ab31358, Abcam), anti-KMT3B (17-10264, Merck Millipore), anti-KDM2A (ab31739, Abcam), antiKDM2B (ab108276, Abcam), anti-KDM4A (ab70786, Abcam), anti-KDM4B (ab80473, Abcam), anti-NF-кB (sc-372G, Santa Cruz), anti-p300 (H-272, Santa Cruz), anti-CEBP $\beta$ (sc-150, Santa Cruz), anti-H3K4me1/2/3 (ab8895/ab7766/ab1012, Abcam), anti-H3K9me1/2/3 (ab9045/ab1220/ab8898, Abcam), anti-H3K27me1/2/3 (ab113671/ab24684/ab6002, Abcam), anti-H3K36me1/2/3 (ab9048/ab9049/ab9050, Abcam), anti-H3K79me1/2/3 (ab2886/ab3594/ab2621, Abcam), anti-H4K20me1/3 (ab9051/9053, Abcam), anti-histone H3 (ab131711, Abcam) and anti- $\beta$-actin (sc-1615, Santa Cruz).

\section{Co-immunoprecipitation (Co-IP)}

H719 and H460 cells were treated with TPA for 2 hours at $100 \mathrm{ng} / \mathrm{mL}$ and then harvested and lysed in lysis buffer (1\% NP-40, $150 \mathrm{mM} \mathrm{NaCl}, 50 \mathrm{mM}$ Tris, $0.05 \%$ SDS, $1 \mathrm{mM}$ PMSF, and a $1 \%$ cocktail of protease inhibitors) on ice for $20 \mathrm{~min}$. Antibodies were then added to the supernatant on ice for 1 hour. The protein was analyzed by Western blotting with different antibodies. Antibodies used for Co-IP are available upon request.

\section{GST pull-down assay}

The His fusion proteins were expressed in bacteria induced with isopropyl- $\beta$-D-thio-galactoside and purified. Equal amounts of His fusion proteins were incubated with glutathione-Sepharose 4B beads (GE Healthcare) and then washed three times with TEN buffer $(20-\mathrm{mM}$ Tris at $\mathrm{pH} 7.4,0.1 \mathrm{mM}$ EDTA, and $100 \mathrm{mM} \mathrm{NaCl}$ ). GSTKDM2A purified from bacteria was incubated with the His fusion proteins. The beads were washed three times with TENT buffer $(0.5 \%$ Nonidet P- $40,20 \mathrm{mM}$ Tris at $\mathrm{pH}$ 7.4, $0.1 \mathrm{mM}$ EDTA, and $300 \mathrm{mM} \mathrm{NaCl}$ ) and analyzed by Western blotting with anti-GST antibody and Coomassie brilliant blue staining.

\section{FRET detection by fluorescence lifetime imaging microscopy (FLIM) analysis}

For the FRET assay, HEK293T cells were cultured for $48 \mathrm{hrs}$ after transfection with pECFP-c-Fos and/ or pEYFP-KDM2A plasmids, on poly-D-lysine-coated coverslips (Fisher Scientific Microscope Cover Glass, 12-545-80, Hampton, NH, USA) and TPA was added for 2 hours . Cells were fixed by $4 \%$ paraformaldehyde and FLIM analysis was performed using a Leica TCS SP8 SMD scanning confocal microscope (Leica Microsystems, Wetzlar, Germany; APO $64 \times / \mathrm{NA}=1.4$, donor activation wavelength $458 \mathrm{~nm}$ ). The FRET assay was performed with TCS SP8 confocal software (Leica, Germany).

\section{Data analysis}

Statistical analysis was performed to assess the difference between two groups under multiple conditions by one-way analysis of variance (ANOVA) using PRISM statistical analysis software (GraphPad Software, Inc., San Diego, CA). The Student's test was performed to assess the difference between two groups in these studies and differences were considered significant at $* p<0.05$, $* * p<0.01$ or $* * * p<0.001$.

\section{ACKNOWLEDGMENTS AND FUNDING}

This work was supported by National Key Basic Research Program of China Grant 2011CB504200 (To WG Zhu), 2012CB517500 (To Y Yang); National Natural Science Foundation of China Grants 31070691, 81321003, 91319302 (To WG Zhu) and 81071676, 81372165, 31261140372 (To Y Yang); Minister of Education of China "111 Project"(To WG Zhu) ; Beijing Natural Science Foundation 5142009 (To Y Yang).

\section{CONFLICTS OF INTEREST}

None of the authors has any conflict of interest to disclose regarding this manuscript.

\section{REFERENCES}

1. Jemal A, Siegel R, Ward E, Hao Y, Xu J, Murray T, Thun MJ. Cancer statistics, 2008. CA Cancer J Clin. 2008; 58:71-96.

2. Boyle P, Ferlay J. Cancer incidence and mortality in Europe, 2004. Ann Oncol. 2005; 16:481-488.

3. Schiller JH, Harrington D, Belani CP, Langer C, Sandler A, Krook J, Zhu J, Johnson DH. Comparison of four chemotherapy regimens for advanced non-small-cell lung cancer. N Engl J Med. 2002; 346:92-98.

4. Han EH, Kim JY, Kim HG, Choi JH, Im JH, Woo ER, Jeong HG. Dihydro-N-caffeoyltyramine down-regulates 
cyclooxygenase-2 expression by inhibiting the activities of C/EBP and AP-1 transcription factors. Food Chem Toxicol. 2010; 48:579-586.

5. Dubois RN, Abramson SB, Crofford L, Gupta RA, Simon LS, A. Van De Putte LB, Lipsky PE. Cyclooxygenase in biology and disease. FASEB J. 1998; 12:1063-1073.

6. Maeng HJ, Lee WJ, Jin QR, Chang JE, Shim WS. Upregulation of COX-2 in the lung cancer promotes overexpression of multidrug resistance protein 4 (MRP4) via PGE2-dependent pathway. Eur J Pharm Sci. 2014; 62:189-196.

7. Riedl K, Krysan K, Pold M, Dalwadi H, Heuze-Vourc'h N, Dohadwala M, Liu M, Cui X, Figlin R, Mao JT, Strieter R, Sharma S, Dubinett SM. Multifaceted roles of cyclooxygenase-2 in lung cancer. Drug Resist Updat. 2004; 7:169-184.

8. Lee JM, Yanagawa J, Peebles KA, Sharma S, Mao JT, Dubinett SM. Inflammation in lung carcinogenesis: new targets for lung cancer chemoprevention and treatment. Crit Rev Oncol Hematol. 2008; 66:208-217.

9. Chun KS, Kim SH, Song YS, Surh YJ. Celecoxib inhibits phorbol ester-induced expression of COX-2 and activation of AP-1 and p38 MAP kinase in mouse skin. Carcinogenesis. 2004; 25:713-722.

10. Chen J, Zhao M, Rao R, Inoue H, Hao CM. C/EBP \{beta\} and its binding element are required for NF\{kappa B-induced COX2 expression following hypertonic stress. J Biol Chem. 2005; 280:16354-16359.

11. Milde-Langosch K. The Fos family of transcription factors and their role in tumourigenesis. Eur J Cancer. 2005; 41:2449-2461.

12. Wagner EF. AP-1 - Introductory remarks. Oncogene. 2001; 20:2334-2335.

13. Miller AD, Curran T, Verma IM. c-fos protein can induce cellular transformation: a novel mechanism of activation of a cellular oncogene. Cell. 1984; 36:51-60.

14. Marsit CJ, Karagas MR, Schned A, Kelsey KT. Carcinogen exposure and epigenetic silencing in bladder cancer. Ann N Y Acad Sci. 2006; 1076:810-821.

15. Barski A, Cuddapah S, Cui K, Roh TY, Schones DE, Wang Z, Wei G, Chepelev I, Zhao K. High-resolution profiling of histone methylations in the human genome. Cell. 2007; 129:823-837.

16. Kouzarides T. Chromatin modifications and their function. Cell. 2007; 128:693-705.

17. Suganuma T, Workman JL. Crosstalk among Histone Modifications. Cell. 2008; 135:604-607.

18. Kane MF, Loda M, Gaida GM, Lipman J, Mishra R, Goldman H, Jessup JM, Kolodner R. Methylation of the hMLH1 promoter correlates with lack of expression of hMLH1 in sporadic colon tumors and mismatch repairdefective human tumor cell lines. Cancer Res. 1997; 57:808-811.
19. Graff JR, Herman JG, Lapidus RG, Chopra H, Xu R, Jarrard DF, Isaacs WB, Pitha PM, Davidson NE, Baylin SB. E-cadherin expression is silenced by DNA hypermethylation in human breast and prostate carcinomas. Cancer Res. 1995; 55:5195-5199.

20. Akhtar M, Cheng Y, Magno RM, Ashktorab H, Smoot DT, Meltzer SJ, Wilson KT. Promoter methylation regulates Helicobacter pylori-stimulated cyclooxygenase-2 expression in gastric epithelial cells. Cancer Res. 2001; 61:2399-2403.

21. Song SH, Jong HS, Choi HH, Inoue H, Tanabe T, Kim NK, Bang YJ. Transcriptional silencing of Cyclooxygenase- 2 by hyper-methylation of the $5^{\prime} \mathrm{CpG}$ island in human gastric carcinoma cells. Cancer Res. 2001; 61:4628-4635.

22. Kera Y, Katoh Y, Ohta M, Matsumoto M, TakanoYamamoto T, Igarashi K. Methionine Adenosyltransferase II-dependent Histone H3K9 Methylation at the COX-2 Gene Locus. J Biol Chem. 2013; 288:13592-13601.

23. El Mansouri FE, Chabane N, Zayed N, Kapoor M, Benderdour M, Martel-Pelletier J, Pelletier JP, Duval N, Fahmi H. Contribution of H3K4 methylation by SET-1A to interleukin-1-induced cyclooxygenase 2 and inducible nitric oxide synthase expression in human osteoarthritis chondrocytes. Arthritis Rheum. 2011; 63:168-179.

24. Coward WR, Feghali-Bostwick CA, Jenkins G, Knox AJ, Pang L. A central role for G9a and EZH2 in the epigenetic silencing of cyclooxygenase-2 in idiopathic pulmonary fibrosis. FASEB J. 2014; 28:3183-3196.

25. Pero R, Peluso S, Angrisano T, Tuccillo C, Sacchetti S, Keller S, Tomaiuolo R, Bruni CB, Lembo F, Chiariotti L. Chromatin and DNA methylation dynamics of Helicobacter pylori-induced COX-2 activation. Int J Med Microbiol. 2011; 301:140-149.

26. Carrozza MJ, Li B, Florens L, Suganuma T, Swanson SK, Lee KK, Shia WJ, Anderson S, Yates J, Washburn MP, Workman JL. Histone H3 methylation by Set2 directs deacetylation of coding regions by Rpd3S to suppress spurious intragenic transcription. Cell. 2005; 123:581-592.

27. Wagner EJ, Carpenter PB. Understanding the language of Lys36 methylation at histone H3. Nat Rev Mol Cell Biol. 2012; 13:115-126.

28. Allis CD, Berger SL, Cote J, Dent S, Jenuwien T, Kouzarides T, Pillus L, Reinberg D, Shi Y, Shiekhattar R, Shilatifard A, Workman J, Zhang Y. New nomenclature for chromatin-modifying enzymes. Cell. 2007; 131:633-636.

29. Tsukada Y, Fang J, Erdjument-Bromage H, Warren ME, Borchers $\mathrm{CH}$, Tempst $\mathrm{P}$, Zhang Y. Histone demethylation by a family of JmjC domain-containing proteins. Nature. 2006; 439:811-816.

30. Cianchi F, Cortesini C, Bechi P, Fantappie O, Messerini L, Vannacci A, Sardi I, Baroni G, Boddi V, Mazzanti R, Masini E. Up-regulation of cyclooxygenase 2 gene expression correlates with tumor angiogenesis in human colorectal cancer. Gastroenterology. 2001; 121:1339-1347. 
31. Toyota M, Shen L, Ohe-Toyota M, Hamilton SR, Sinicrope FA, Issa JP. Aberrant methylation of the Cyclooxygenase $2 \mathrm{CpG}$ island in colorectal tumors. Cancer Res. 2000; 60:4044-4048.

32. Berger SL. The complex language of chromatin regulation during transcription. Nature. 2007; 447:407-412.

33. Cedar H, Bergman Y. Linking DNA methylation and histone modification: patterns and paradigms. Nat Rev Genet. 2009; 10:295-304.

34. Bannister AJ, Schneider R, Myers FA, Thorne AW, CraneRobinson C, Kouzarides T. Spatial distribution of di- and tri-methyl lysine 36 of histone $\mathrm{H} 3$ at active genes. J Biol Chem. 2005; 280:17732-17736.

35. Kimura H. Histone modifications for human epigenome analysis. J Hum Genet. 2013; 58:439-445.

36. Landry J, Sutton A, Hesman T, Min J, Xu RM, Johnston M, Sternglanz R. Set2-catalyzed methylation of histone H3 represses basal expression of GAL4 in Saccharomyces cerevisiae. Mol Cell Biol. 2003; 23:5972-5978.

37. Li B, Jackson J, Simon MD, Fleharty B, Gogol M, Seidel C, Workman JL, Shilatifard A. Histone H3 lysine 36 dimethylation (H3K36me2) is sufficient to recruit the Rpd3s histone deacetylase complex and to repress spurious transcription. J Biol Chem. 2009; 284:7970-7976.

38. Berdasco M, Ropero S, Setien F, Fraga MF, Lapunzina P, Losson R, Alaminos M, Cheung N-K, Rahman N, Esteller M. Epigenetic inactivation of the Sotos overgrowth syndrome gene histone methyltransferase NSD1 in human neuroblastoma and glioma. Proc Natl Acad Sci U S A. 2009; 106:21830-21835.

39. Cao LL, Wei F, Du Y, Song B, Wang D, Shen C, Lu X, Cao Z, Yang Q, Gao Y, Wang L, Zhao Y, Wang H, et al. ATM-mediated KDM2A phosphorylation is required for the DNA damage repair. Oncogene. 2015; 10.1038/ onc.2015.81.

40. Wagner KW, Alam H, Dhar SS, Giri U, Li N, Wei Y, Giri D, Cascone T, Kim JH, Ye Y, Multani AS, Chan CH, Erez B, et al. KDM2A promotes lung tumorigenesis by epigenetically enhancing ERK1/2 signaling. J Clin Invest. 2013; 123:5231-5246.

41. Huang Y, Liu Y, Yu L, Chen J, Hou J, Cui L, Ma D, $\mathrm{Lu} \mathrm{W}$. Histone demethylase KDM2A promotes tumor cell growth and migration in gastric cancer. Tumour Biol. 2015; $36: 271-8$.

42. Rizwani W, Schaal C, Kunigal S, Coppola D, Chellappan S. Mammalian lysine histone demethylase KDM2A regulates E2F1-mediated gene transcription in breast cancer cells. PLoS One. 2014; 9:e100888.

43. Min L, Ji Y, Bakiri L, Qiu Z, Cen J, Chen X, Chen L, Scheuch H, Zheng H, Qin L, Zatloukal K, Hui L, Wagner EF. Liver cancer initiation is controlled by AP-1 through SIRT6-dependent inhibition of survivin. Nat Cell Biol. 2012; 14:1203-1211.

44. Chen KC, Liao YC, Hsieh IC, Wang YS, Hu CY, Juo SH. OxLDL causes both epigenetic modification and signaling regulation on the microRNA-29b gene: novel mechanisms for cardiovascular diseases. J Mol Cell Cardiol. 2012; 52:587-595.

45. Zhu W-G, Srinivasan K, Dai Z, Duan W, Druhan LJ, Ding H, Yee L, Villalona-Calero MA, Plass C, Otterson GA. Methylation of Adjacent CpG Sites Affects Sp1/Sp3 Binding and Activity in the p21Cip1 Promoter. Mol Cell Biol. 2003; 23:4056-4065.

46. Yang Y, Zhao Y, Liao W, Yang J, Wu L, Zheng Z, Yu Y, Zhou W, Li L, Feng J, Wang H, Zhu WG. Acetylation of FoxO1 activates Bim expression to induce apoptosis in response to histone deacetylase inhibitor depsipeptide treatment. Neoplasia. 2009; 11:313-324.

47. Yang Y, Ikezoe T, Nishioka C, Bandobashi K, Takeuchi T, Adachi Y, Kobayashi M, Takeuchi S, Koeffler HP, Taguchi H. NFV, an HIV-1 protease inhibitor, induces growth arrest, reduced Akt signalling, apoptosis and docetaxel sensitisation in NSCLC cell lines. Br J Cancer. 2006; 95:1653-1662.

48. Zhu W-G, Lakshmanan RR, Beal MD, Otterson GA. DNA Methyltransferase Inhibition Enhances Apoptosis Induced by Histone Deacetylase Inhibitors. Cancer Res. 2001; 61:1327-1333. 